NASA/TM-2006-214087
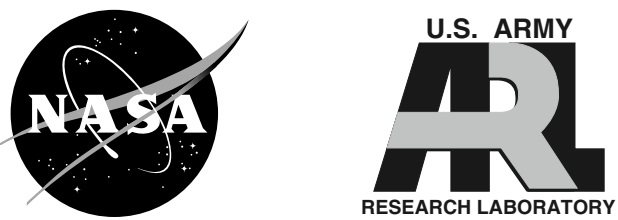

\title{
Advances in Engine Test Capabilities at the NASA Glenn Research Center's Propulsion Systems Laboratory
}

Peter M. Pachlhofer and Joseph W. Panek

Glenn Research Center, Cleveland, Ohio

Dennis J. Dicki, Barry R. Piendl, and Paul J. Lizanich

QSS Group, Inc., Cleveland, Ohio

Gary A. Klann

U.S. Army Research Laboratory, Glenn Research Center, Cleveland, Ohio 


\section{NASA STI Program . . . in Profile}

Since its founding, NASA has been dedicated to the advancement of aeronautics and space science. The NASA Scientific and Technical Information (STI) program plays a key part in helping NASA maintain this important role.

The NASA STI Program operates under the auspices of the Agency Chief Information Officer. It collects, organizes, provides for archiving, and disseminates NASA's STI. The NASA STI program provides access to the NASA Aeronautics and Space Database and its public interface, the NASA Technical Reports Server, thus providing one of the largest collections of aeronautical and space science STI in the world. Results are published in both non-NASA channels and by NASA in the NASA STI Report Series, which includes the following report types:

- TECHNICAL PUBLICATION. Reports of completed research or a major significant phase of research that present the results of NASA programs and include extensive data or theoretical analysis. Includes compilations of significant scientific and technical data and information deemed to be of continuing reference value. NASA counterpart of peer-reviewed formal professional papers but has less stringent limitations on manuscript length and extent of graphic presentations.

- TECHNICAL MEMORANDUM. Scientific and technical findings that are preliminary or of specialized interest, e.g., quick release reports, working papers, and bibliographies that contain minimal annotation. Does not contain extensive analysis.

- CONTRACTOR REPORT. Scientific and technical findings by NASA-sponsored contractors and grantees.
- CONFERENCE PUBLICATION. Collected papers from scientific and technical conferences, symposia, seminars, or other meetings sponsored or cosponsored by NASA.

- SPECIAL PUBLICATION. Scientific, technical, or historical information from NASA programs, projects, and missions, often concerned with subjects having substantial public interest.

- TECHNICAL TRANSLATION. Englishlanguage translations of foreign scientific and technical material pertinent to NASA's mission.

Specialized services also include creating custom thesauri, building customized databases, organizing and publishing research results.

For more information about the NASA STI program, see the following:

- Access the NASA STI program home page at http://www.sti.nasa.gov

- E-mail your question via the Internet to help@sti.nasa.gov

- Fax your question to the NASA STI Help Desk at 301-621-0134

- Telephone the NASA STI Help Desk at 301-621-0390

- Write to:

NASA STI Help Desk

NASA Center for AeroSpace Information 7121 Standard Drive Hanover, MD 21076-1320 

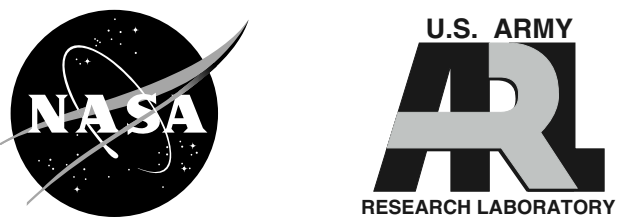

\section{Advances in Engine Test Capabilities at the NASA Glenn Research Center's Propulsion Systems Laboratory}

Peter M. Pachlhofer and Joseph W. Panek

Glenn Research Center, Cleveland, Ohio

Dennis J. Dicki, Barry R. Piendl, and Paul J. Lizanich

QSS Group, Inc., Cleveland, Ohio

Gary A. Klann

U.S. Army Research Laboratory, Glenn Research Center, Cleveland, Ohio

Prepared for

Turbo Expo 2006

sponsored by the American Society of Mechanical Engineers

Barcelona, Spain, May 8-11, 2006

National Aeronautics and

Space Administration

Glenn Research Center

Cleveland, Ohio 44135 


\section{Acknowledgments}

The authors thank Joseph E. Rossoll, Mark R. Woike, Ruben Del Rosario,

Roger Chamberlin, and Alan A. Linne for their reviews of this paper.

Level of Review: This material has been technically reviewed by technical management.

Available from

NASA Center for Aerospace Information

7121 Standard Drive

Hanover, MD 21076-1320
National Technical Information Service 5285 Port Royal Road Springfield, VA 22161

Available electronically at http://gltrs.grc.nasa.gov 


\title{
Advances in Engine Test Capabilities at the NASA Glenn Research Center's Propulsion Systems Laboratory
}

\author{
Peter M. Pachlhofer and Joseph W. Panek \\ National Aeronautics and Space Administration \\ Glenn Research Center \\ Cleveland, Ohio 44135 \\ Dennis J. Dicki, Barry R. Piendl, and Paul J. Lizanich \\ QSS Group, Inc. \\ Cleveland, Ohio 44135 \\ Gary A. Klann \\ NASA Glenn Research Center \\ U.S. Army Research Laboratory \\ Cleveland, Ohio 44135
}

\begin{abstract}
The Propulsion Systems Laboratory at the National Aeronautics and Space Administration (NASA) Glenn Research Center is one of the premier U.S. facilities for research on advanced aeropropulsion systems. The facility can simulate a wide range of altitude and Mach number conditions while supplying the aeropropulsion system with all the support services necessary to operate at those conditions. Test data are recorded on a combination of steadystate and high-speed data-acquisition systems.

Recently a number of upgrades were made to the facility to meet demanding new requirements for the latest aeropropulsion concepts and to improve operational efficiency. Improvements were made to data-acquisition systems, facility and engine-control systems, test-condition simulation systems, video capture and display capabilities, and personnel training procedures. This paper discusses the facility's capabilities, recent upgrades, and planned future improvements.
\end{abstract}

\section{Introduction}

To meet the needs of demanding new test requirements for the latest aeropropulsion concepts, the NASA Glenn Research Center has upgraded the capabilities of its Propulsion Systems Laboratory (PSL). The improvements have increased operational efficiencies and provide customers with a more versatile facility with the highest accuracy test data possible.

To a large extent, the decisions to pursue certain advances in test capabilities were driven by the needs of PSL's customers. Present and future programs are looking for higher altitude test conditions and higher Mach number and temperature capabilities. The need to operate efficiently and effectively is a major concern, and the cost of each test program is being scrutinized. Moreover, access to real-time, highly accurate test data and results is of paramount importance to the organizations that rely on this facility.

The upgrades and planned improvements discussed in this paper address many of these concerns. Mechanical system improvements were made in the PSL's ability to provide large quantities of reliable cold air, high-altitude conditions, and heated air for higher Mach number conditions. Future improvements, covered in this paper, call for generating altitude icing and mixed-phase conditions for engine certification requirements, which are becoming increasingly more stringent. Electronic improvements have focused on sophisticated facility control, data acquisition, and display capabilities. Investments have been made in state-of-the-art Ovation (Emerson Process Management, Austin, TX) and Modicon/Wonderware facility control systems (Wonderware, Lake Forest, CA) to reduce test times and Dewetron high-speed data systems (Dewetron, Inc., Charlestown, RI) that provide the highest level of flexibility and ease of use.

Research performed at the PSL provides detailed information on the performance and operability of engines and propulsion systems at extreme conditions over the entire flight envelope, which can only be obtained through altitude-simulated, ground-based testing. The scientists and engineers that employ their capabilities at the PSL are experts in engine performance, maintenance, operations, aeroelastic measurements, flight transient operations, and transient temperature and pressure distortion simulations. The facility supports the development of new technology that is critical to national defense and security. The PSL has supported such aircraft programs as the SR-71, F-16, F-15 short takeoff and landing (STOL), and the B-52 and has conducted basic research on advanced aircraft, space transportation, general aviation propulsion, and hypersonic propulsion. 


\section{Facility Overview}

The PSL is NASA's only large, ground-based engine test facility. This modern facility is designed for research and development activities. It provides detailed information on the performance and operability of engines and propulsion systems at extreme conditions over the entire flight envelope. A continuous-flow altitude facility, the PSL is equipped with a suite of advanced data-acquisition and analysis equipment to conduct full-scale and component testing for base research, advanced aircraft, space transportation, general aviation propulsion, and hypersonic propulsion.

Construction of the PSL was completed in 1969, and the facility became operational in 1973. The complex consists of two test chambers-PSL-3 and PSL-4-which are $24 \mathrm{ft}$ $(7.3 \mathrm{~m})$ in diameter and $38 \mathrm{ft}(11.6 \mathrm{~m})$ long. PSL-3 simulates forward speeds of up to Mach 3.0 and has been optimized for fighter-class turbine engine testing. In 1990, an inner inlet plenum that can run at 165 psia $(1138 \mathrm{kPa})$ and $1200{ }^{\circ} \mathrm{F}\left(649{ }^{\circ} \mathrm{C}\right)$ was installed in PSL -4 to provide highMach-number conditions. This enables PSL-4 to run at speeds up to approximately Mach 4. Each test chamber can provide simulated altitude conditions from near sea level up to $80000 \mathrm{ft}(24.4 \mathrm{~km})$, depending on engine airflow requirements. An altitude of $90000 \mathrm{ft}(27.4 \mathrm{~km})$ can be simulated for flow rates of approximately $10 \quad \mathrm{lb} / \mathrm{m}$ $(4.5 \mathrm{~kg} / \mathrm{s})$. General operating envelopes of the two test chambers are shown in figure 1.

The two test cells (see fig. 2) normally operate as directconnect engine test cells that are coupled to Glenn's central air supply system. Total airflow rates up to $480 \mathrm{lb}_{\mathrm{m}} / \mathrm{s}$ $(218 \mathrm{~kg} / \mathrm{s})$ are possible. Onsite turboexpanders are used to create the cold air temperatures, and J57 engines with natural gas afterburners flowing into heat exchangers are used to provide nonvitiated heated air. Atmospheric air also can be supplied to the engine inlets. Both test cells are connected to a common exhaust, a primary cooler, and a secondary spray cooler. With this configuration, only one test cell can be operated at a time.

A wide variety of propulsion systems can be tested at the PSL. A typical medium-sized turbofan engine installation is shown in figure 3 with the engine inlet direct connected to the supply air.

The test cell can also be set up in a free-jet configuration. In addition, the test cell's altitude capability has been used to support unusual tests such as the high-altitude balloon gondola shown in figure 4.

Because of the nature of research testing and the wide variety of engines tested in the PSL, test cell configurations can completely change between test programs. Therefore, facility and engine installation times for each entry vary but typically take 6 weeks. Turnaround times between engine

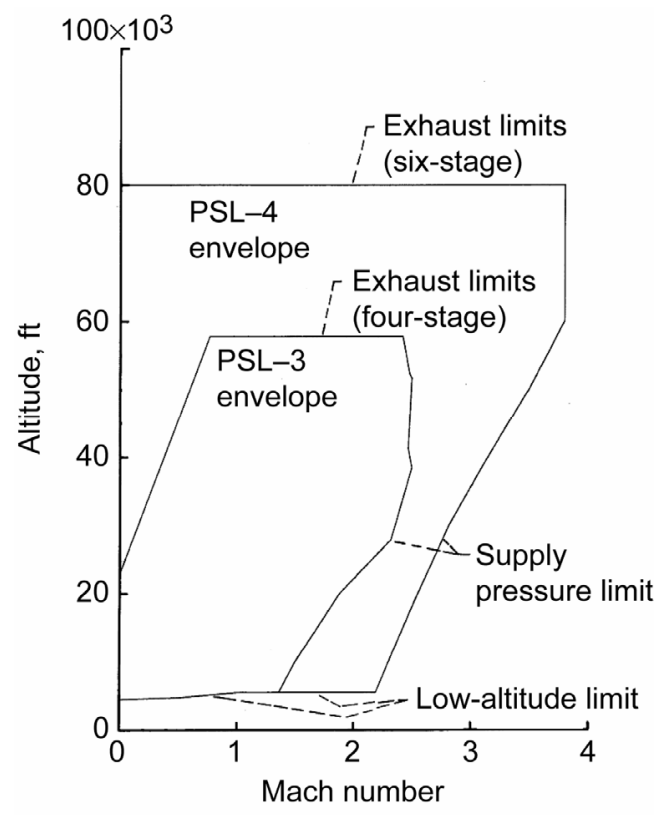

Figure 1.-Operating envelopes for PSL-3 and PSL-4.

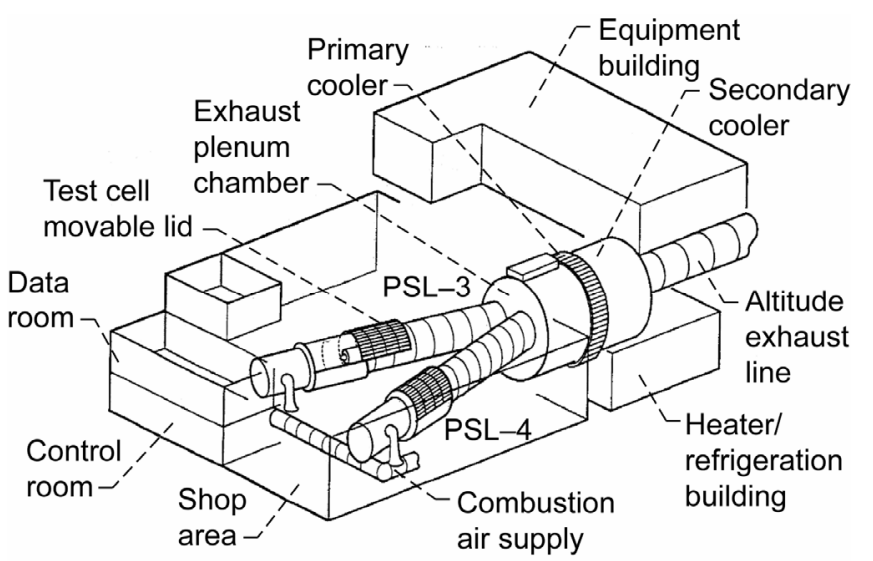

Figure 2.-PSL-3 and PSL-4 (ref. 1).

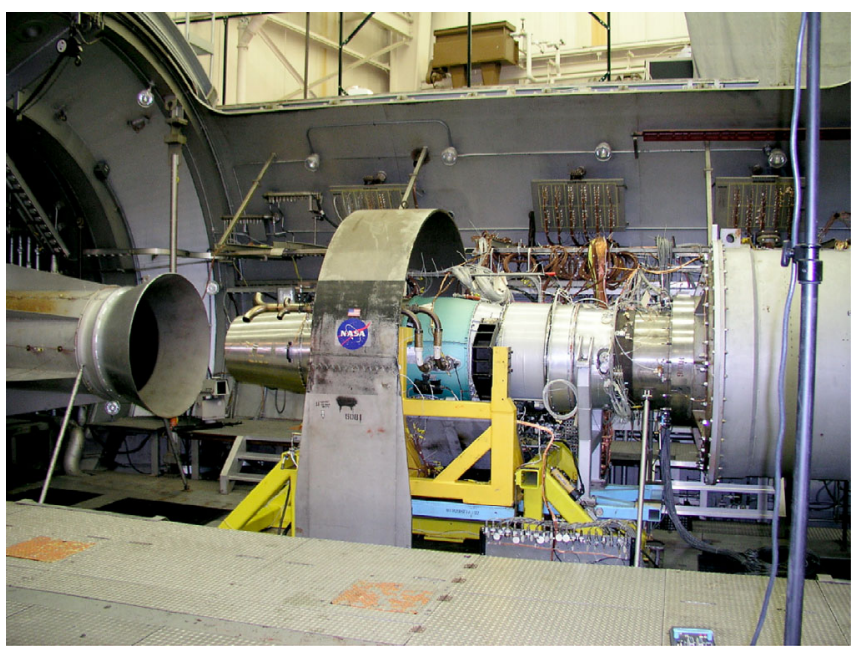

Figure 3.-PSL-4 engine installation. 


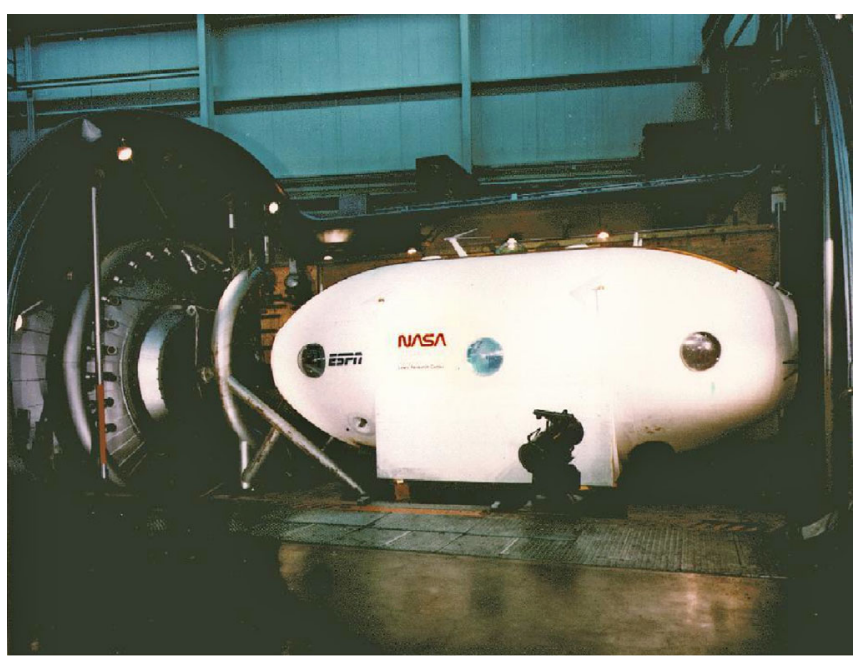

Figure 4.-High-altitude balloon gondola installation.

entries are shortened when similar engines are scheduled. The length of a test program depends solely on the testing requirements.

Air periods are available 5 nights per week and are scheduled in conjunction with PSL customer requirements and the needs of other Glenn facilities for combustion air and altitude exhaust. Test data and online analysis are provided at the facility in real time and are transmitted to customer sites over dedicated data-transmission lines. Batch data analysis can be initiated when needed and transmitted. Table I summarizes the capabilities of the test cell and the various support systems.

A more detailed description of the PSL can be found in the facility user manual (ref. 1). In addition, information about the PSL is available on Glenn's facilities Web site (http://facilities.grc.nasa.gov).

\section{Engine Test Capability Advances}

\section{Facility Controls Improvements}

The PSL facility is controlled by an Ovation distributed process-control system. The system has seven input-output drops, each of which is controlled by a pair of redundant distributed process units. These units contain the control logic to operate the facility and its support systems. The units read process input data from the input-output drops, scale the input data, perform limit checks and control functions, and write the output data to the input-output drops. The distributed process units are networked to each other as well as to four operator stations and an engineer's console. The facility control data to these stations and the console are constantly updated and displayed on 10 video displays. A server on the network continuously logs historical information.
The Ovation control system represents a major upgrade to the PSL facility with many improvements over its predecessor. The new system is easier to program and has greatly improved methods of documentation. It has improved data trending and alarming capabilities in addition to enhanced historical recall features. The Windows 2000 (Microsoft Corporation, Redmond, WA) operating system on the workstations allows multiple windows to be opened, thereby permitting easier troubleshooting and maintenance. The new Windows interface allows changes to be implemented more efficiently than the previous operating system did, resulting in cost savings to the PSL and its customers.

\section{TABLE I.-PSL CHARACTERISTICS (ref. 1)}

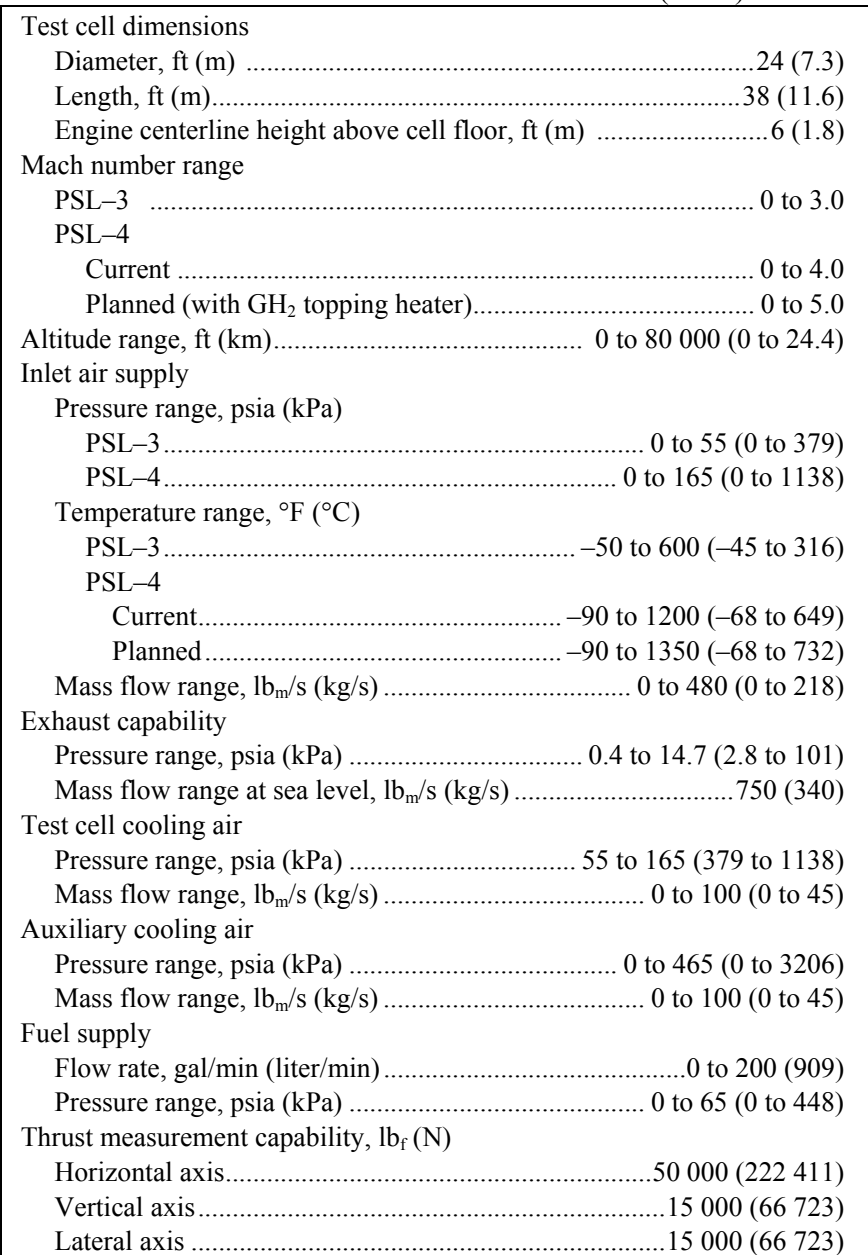

\section{Transient Data Improvements}

Two new transient data systems were placed into service in the PSL. The first acquires analog data, and the second acquires MIL-STD-1553 data. In addition, an internal data network was established to easily transfer data to data servers and customer machines. 


\section{Dewetron Analog Transient Data-Acquisition System}

The new Dewetron 62-channel system greatly enhances the capturing and viewing of real-time engine events. Engineering unit data can be viewed in real time to enhance researchers' ability to discern the status of test articles (see fig. 5). In addition, real-time scope, fast Fourier transform, power spectral density, $x-y$, chart recorder, numeric, and "cockpit" displays can be modified in real time to meet custom requirements. Many data-exporting and postanalysis options are available.

A sigma-delta analog-to-digital converter, 24 bits per channel, offers a dynamic range of well over $84 \mathrm{~dB}$, requires no expensive external antialiasing filters, and provides synchronized data. The system's dynamic range is beyond the signal-to-noise ratio of standard analog transducers in a test cell environment. Integral signal conditioners provide filtering and amplification to match the transducer signals to the analog-to-digital converter's sampling rate and input range. Sampling rates from 1000 to 200000 samples per second per channel are supported. Inter-Range Instrument Group, Standard B (IRIG B) time stamping is provided to synchronize data from a number of sources.

Analog channels can be displayed in engineering units, raw voltage, or both. In addition, derived "math" channels can be calculated, displayed, and stored along with analog data. These math channels can be used to calculate items such as corrected flow, average temperatures, or pressure ratios. Online integration and differentiation (single and double) as well as digital filtering are available.

Graphical displays utilize real-time zooming along with user-configurable cursors to enable effective viewing and measuring of data. Each display parameter has a separate $y$-axis to help with viewing low- and high-level signals on a single graph. A vibration signal scale from 0 to $0.1 \mathrm{in} . / \mathrm{s}$ ( 0 to $0.254 \mathrm{~cm} / \mathrm{s}$ ) and a temperature scale from 750 to $850{ }^{\circ} \mathrm{F}$ (399 to $454^{\circ} \mathrm{C}$ ) can be placed on the same graph. Numeric displays can be set to average, root mean square, peak-to-peak, actual, minimum, or maximum values. Limits can be applied to displayed values to more easily track outof-limit conditions.

Numerous export file types are supported, including Microsoft Excel, MATLAB (The MathWorks, Natick, MA), tab-delimited, and many other standard formats. If the data of interest are only 2 seconds out of 10 seconds of recorded data, just the 2 seconds can be selected and exported. Such "data cropping" can be utilized to reduce the size of the exported file.

The Dewesoft software can be loaded onto a customer's machine running Microsoft Windows at no cost and be utilized for analysis. This software is easy to learn yet powerful enough to provide many options for data analysis. Data can be "played" using digital video disc- (DVD-) like controls. The playback speed can be adjusted from 1/2000 to 5000 times real time and can be paused and reversed. The displays used to view data in real time can be used as is or can be modified to view key information. If a fast Fourier transform is not among the displays selected for real-time viewing, it can be added for postanalysis, and if the scaling of an oscilloscope display is too large, it can be reduced to enable easier viewing of the data.

The transient data system is configured for flexibility (fig. 6). A secure means for customers to connect their own machines to the PSL data network is provided to allow for near-real-time postanalysis using the customer's own software. Customers also can take advantage of the MATLAB analysis system that is provided by the facility. Standard time trace and fast Fourier transform displays are available as well as custom export options. The Dewetron system is being expanded to 124 channels.

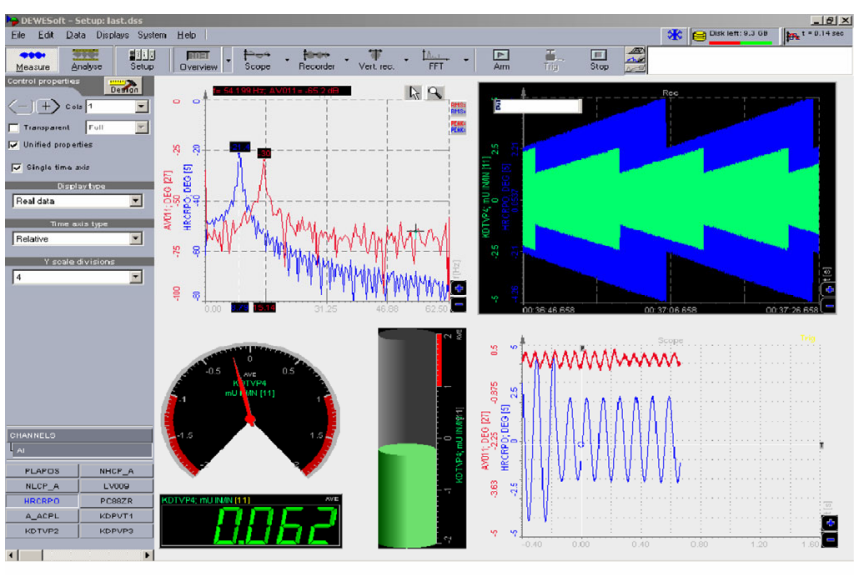

Figure 5.-Typical display of the PSL transient data-acquisition system.

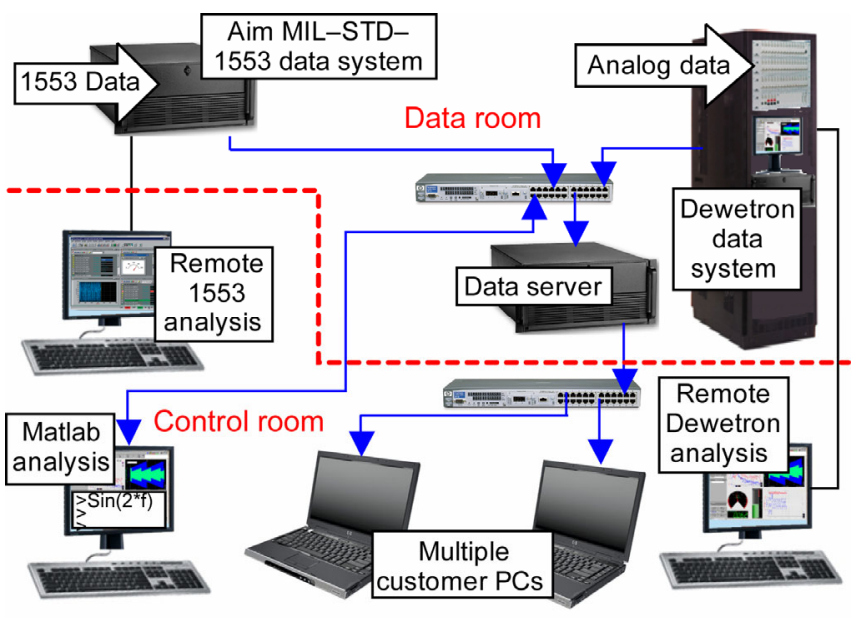

Figure 6.-Configuration of the PSL transient data-acquisition system. 


\section{Aim MIL-STD-1553 Data-Acquisition System}

The new Aim MIL-STD-1553 data-acquisition system provides bus monitoring of two independent, dual-redundant buses. The system uses an onboard IRIG-B time-code decoder to time-stamp all 1553 messages. The customer bus controller and remote terminals are connected to the PSL 1553 bus via transformers.

The typical 1553 data-acquisition configuration enables one bus-monitoring interface to continuously record all messages to disk (safety tape mode), and it sets up the other bus-monitoring interface for external trigger operation. The external trigger mode allows customers to control the recording of 1553 messages over specific areas of interest.

An intuitive graphical user interface gives customers the ability to easily set up complex bus monitoring and recording functions. Stored data can be exported to commaseparated variable files, tab-delimited American Standard Code for Information Interchange (ASCII) files, or binaryformatted files. Near-real-time viewing of recorded data files is supported via third-party software.

The new Dewetron and Aim systems provide a powerful, flexible means for PSL's customers to quickly evaluate, record, and analyze transient engine parameters.

\section{Pressure Measurement Improvements}

The current electronically scanned pressure measurement system in the PSL utilizes the Esterline Pressure System Incorporated's System 8400 (Esterline Technologies, Bellevue, WA) with rack-mount pressure scanners. The system has undergone a number of improvements over the years (ref. 2). One of the most significant has been the addition of a temperature-controlled enclosure for the system. The enclosure is located just outside of the test chamber and maintains the temperature to approximately $75^{\circ} \mathrm{F}\left(23.9^{\circ} \mathrm{C}\right)$, with scanner temperature variations of less than $\pm 1.5^{\circ} \mathrm{F}$ $\left(0.8{ }^{\circ} \mathrm{C}\right)$. This temperature control allows the system to remain within the \pm 0.05 -percent full-scale (FS) accuracy specification for 2 to 3 hours at a time. Without the temperature control, at least two calibrations would have to be performed each hour to maintain the system to within specifications. For a typical 6-hr testing period, this increases the effective testing time from 92.4 to 98.6 percent with calibration times of $2.5 \mathrm{~min}$.

Future pressure-measurement enhancements include the transitioning of the current System 8400 to an Ethernetbased rack-mount pressure system with digitally compensated transducers. This new system will provide the same \pm 0.05 -percent FS accuracy but will only need to be calibrated once every 6 months as opposed to the periodic in situ calibrations that are currently required. This will increase the effective testing time even further and decrease calibration costs. These systems utilize digital temperature

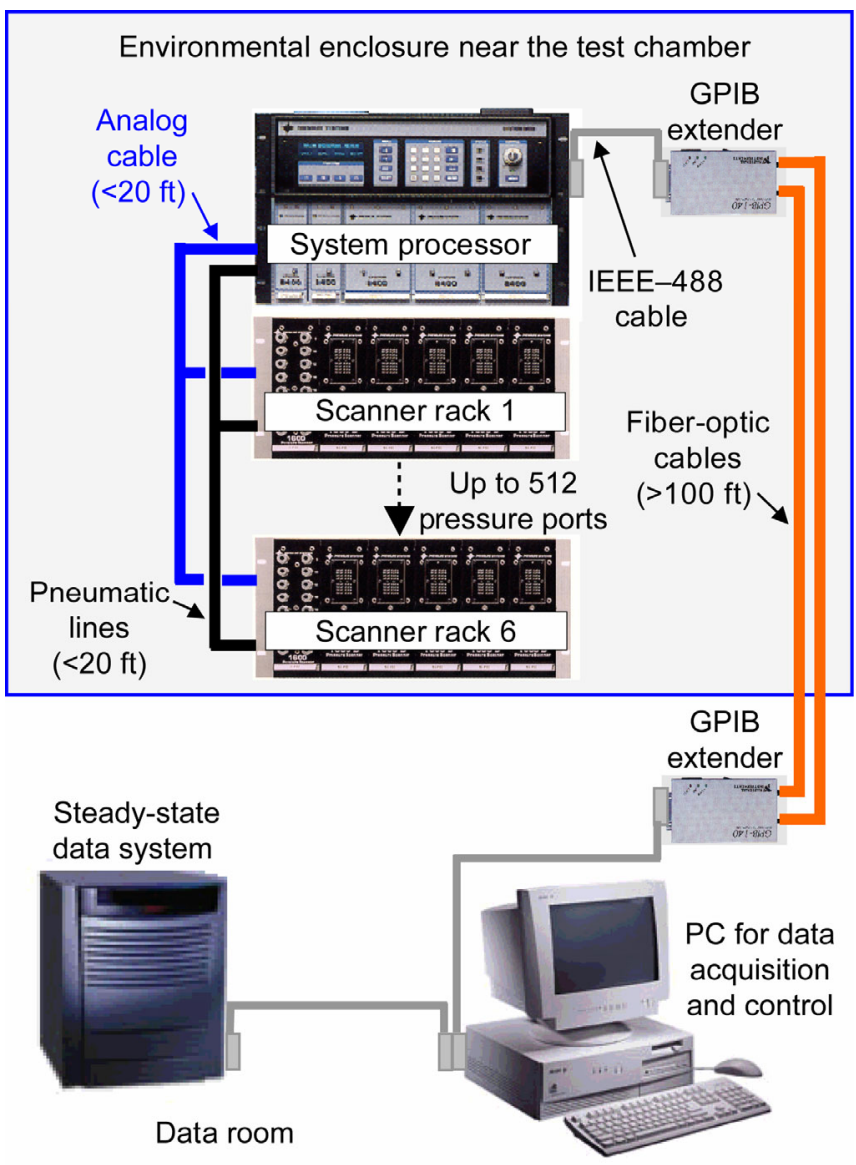

Figure 7.-PSL pressure-measurement system. GPIB, general-purpose interface bus.

compensation to maintain the stated accuracy over a temperature range of approximately 32 to $131{ }^{\circ} \mathrm{F}$ ( 0 to $\left.55^{\circ} \mathrm{C}\right)$. The system scanners can be remotely rezeroed or placed in purge mode to force contaminants out of the pressure lines. Figure 7 shows a diagram of the current PSL pressure-measurement system.

\section{Video Imaging and Recording Improvements}

The PSL video system has undergone a major updating impacting all aspects of the system. Each test cell has four cameras, one nominally in each corner of the chamber, which are used to monitor the test. In addition, numerous other cameras around the complex are used to monitor other facility subsystems. Each of these cameras has been replaced with new cameras and lenses. These cameras produce 480-line National Television System Committee color video images that automatically switch to black-and-white images at 0.7 lux to extend low-light operation down to 0.05 lux. Although the test cell is fully illuminated during testing, this feature is especially useful for the cameras that monitor facility subsystems located outside of the complex. The lenses provide a motorized 15:1 optical zoom. 
The cameras can pan and tilt and are all mounted in enclosures to protect them from the local environment. Each of these functions is controllable from the control room. Plans include further simplifying the video system operation by integrating video control through a quantum programmable logic controller.

In addition to these basic test cell cameras, the facility has recently acquired a single 850-line high-resolution television camera for each test cell. These cameras are mounted in enclosures in the aft portion of the test cell to provide a superior image of the back of the engine. The facility also has provisions for a periscope camera in the exhaust to provide images directly up the aft of the engine. These cameras also are controllable from the control room. Each of these video sources is passed through character generators that imprint the camera name on the image to aid in locating the appropriate pan/tilt and camera controls. In addition, a video overlay system imprints the time code on all images that originate in the test cell to enable synchronization of images with data.

The main control room video displays have been replaced with 10 new studio-quality 20 -in. $(51-\mathrm{cm})$ monitors located in the front of the control room. In addition, both the test conductor and customer are provided with six small liquidcrystal-display (LCD) monitors to view the test cell, and an individual video switch to select the source for a personal 20-in. (51-cm) LCD monitor.

The facility has upgraded its recording capability from videocassette recorders (VCRs) and early-generation DVD recorders to six modern, medical-grade DVD recorders. A new JVC VCR (JVC Company of America, Wayne, NJ) also is provided to support legacy recordings. The output of each of these DVD recorders is directly routed to additional 5.6-in. (14.2-cm) LCD monitors to enable easy verification of device recording. A DVD duplicator enables the rapid creation of up to seven duplicates of a single DVD at a time.

The facility video-patching system has been replaced with a state-of-the-art video-signal-processing system. This system's present configuration permits any of 32 userselectable input sources to be routed to any of 48 output devices, such as a video-recording or display device in the control room.

In a typical configuration, five of the main monitors display the periscope and four basic test cell images, and the remaining five monitors display facility subsystem images. A 37-in. (94-cm) high-definition television monitor displays the high-resolution camera. Images from the four basic cameras, one high-resolution camera, and a periscope camera are typically routed to DVD recorders and subsequently to their monitoring LCDs. Images from these six cameras, along with up to two additional images, are routed to both the test conductor monitor LCDs and switch, and to the customer monitor LCDs and switch.

\section{Safety Recording System Improvements}

Further improvements were made to the facility safety data system. An integrated data recorder was installed that records up to 32 voltage channels to a $25-\mathrm{GB}$ advanced intelligence data cartridge tape. The system can record data from 1 to 200000 samples per second. The typical safety tape operation is to sample at a combination of 1000 and 10000 samples per second, enabling the system to run continuously through an entire test run without the need to change tape. The system continuously writes the information to the data tape, but it can also be continuously displayed on a computer monitor. A number of channels are reserved for facility monitoring, with the remaining channels available for customer definition. In the event of an incident, the data stored on the tape can be copied as a TEAC Data Acquisition File Format (TAFFmat) file (TEAC Corporation, Tokyo, Japan) to a dedicated personal computer, where it can be read using GX View software.

The PSL recently replaced its strip chart display devices with a new digital chart recorder. The recorder has 16 general-purpose true differential input ports with up to \pm 20 -V full-scale and eight thermocouple input ports. It supports a system with a maximum, aggregate throughput rate of 1 million samples per second. In addition, the recorder includes a math module that enables the unit to perform calculations on combinations of input. Multiple userconfigurable display pages are available, each with up to 16 input sources or calculations per page.

The video-switching equipment and DVD recorders, safety data tape, and digital chart recorder are all protected from loss of power with uninterruptible power supplies.

\section{Conference Room and Customer Office Improvements}

The PSL includes a customer office containing a conference table, dry erase marker board, phone, fax, and workspace, along with a facility conference room. Recent improvements to the conference room include a new stateof-the-art integrated audio-video projection system. This new system includes a $10-\mathrm{ft}(3-\mathrm{m})$ remotely operated selftensioning screen, a digital-light-processing projector that is bright enough to use while the room is illuminated normally, and a two-channel audio system, all tied together via a media switch. The media switch enables an operator to route any of six input devices to the audiovideo systems. A computer with a wireless keyboard and mouse, a full Microsoft Office suite, and DVD/CD drives are provided. A DVD player and a VCR with a connection to the NASA cable television system complete the system. In addition, a front panel input port is provided so that a customer can connect his or her own extended video graphics array (XVGA) source, such as a laptop computer. Plans include upgrading the current overhead slide capability to a digital document 
camera system that will be integrated into the audiovideo switching system in the near term.

\section{Engine Core and High-Mach-Number Testing Improvements}

A new preheater was recently added to the PSL to expand its capability for engine core and high-Mach-number propulsion system test applications. Altitude testing of the core of a jet engine requires specialized subsystems that can simulate the functions of the low-pressure spool. One of the primary functions of this spool is to provide high-pressure air to the engine core. This air, which is at temperatures higher than ambient, is also used for turbine cooling and inbleed.

To meet this unique test requirement and simulate this condition in a ground-based altitude test facility, a naturalgas-fired, nonvitiated air heater was designed and installed in the PSL (see fig. 8). The piping for this heater currently runs only into PSL -4 , with provisions made to later extend it to PSL-3. The heater is designed to heat $39 \mathrm{lb}_{\mathrm{m}} / \mathrm{s}$ $(17.7 \mathrm{~kg} / \mathrm{s})$ of $465-\mathrm{psia}(3206-\mathrm{kPa})$ air to a temperature of $1200{ }^{\circ} \mathrm{F}\left(649{ }^{\circ} \mathrm{C}\right)$ (see fig. 9). The air is delivered into the test cell through a 10 -in.- (25.4-cm-) diameter pipe. A 4-in.$(10.2-\mathrm{cm}-)$ diameter line vents into the exhaust duct for warmups and cooldowns of the heater.

An additional connection, to the unheated 465-psia (3206-kPa) cooling air supply, enables blending of heated and unheated air so that temperatures from ambient to $1200{ }^{\circ} \mathrm{F}\left(649^{\circ} \mathrm{C}\right)$ can be supplied to the test article. The blending further enables a larger flow rate of air, up to $100 \mathrm{lb}_{\mathrm{m}} / \mathrm{s}(45.3 \mathrm{~kg} / \mathrm{s})$ at $500{ }^{\circ} \mathrm{F}\left(260{ }^{\circ} \mathrm{C}\right)$, to be delivered to the test article in the test chamber.

In order to meet the temperature requirements for highMach-number testing at altitude, the air heater was designed for dual use with either 465-psia (3206-kPa) or 165-psia $(1138-\mathrm{kPa})$ air-supply systems. With the 165-psia $(1138-\mathrm{kPa})$ air, a higher temperature of $1350{ }^{\circ} \mathrm{F}\left(732^{\circ} \mathrm{C}\right)$ at flow rates up to $25 \mathrm{lb}_{\mathrm{m}} / \mathrm{s}(11.3 \mathrm{~kg} / \mathrm{s})$ can be supplied to the test article. This temperature corresponds to a simulated flight condition of approximately Mach 4.3.

Other propulsion system applications require larger quantities of airflow at somewhat lower temperature levels. The PSL uses two J57 engines with shell and tube heat exchangers (see fig. 10) to heat the combustion air that is fed to the research engines installed in the test chambers. This system was designed to operate at $1200{ }^{\circ} \mathrm{F}\left(649{ }^{\circ} \mathrm{C}\right)$; however, the high differential temperatures at the face of the tube sheet of the heat exchanger limit its operating temperature. This situation is caused by the characteristics of the natural-gas-fired afterburner located behind the J57 engines. Several modifications have been made to the system to get a more uniform temperature, and additional upgrades are

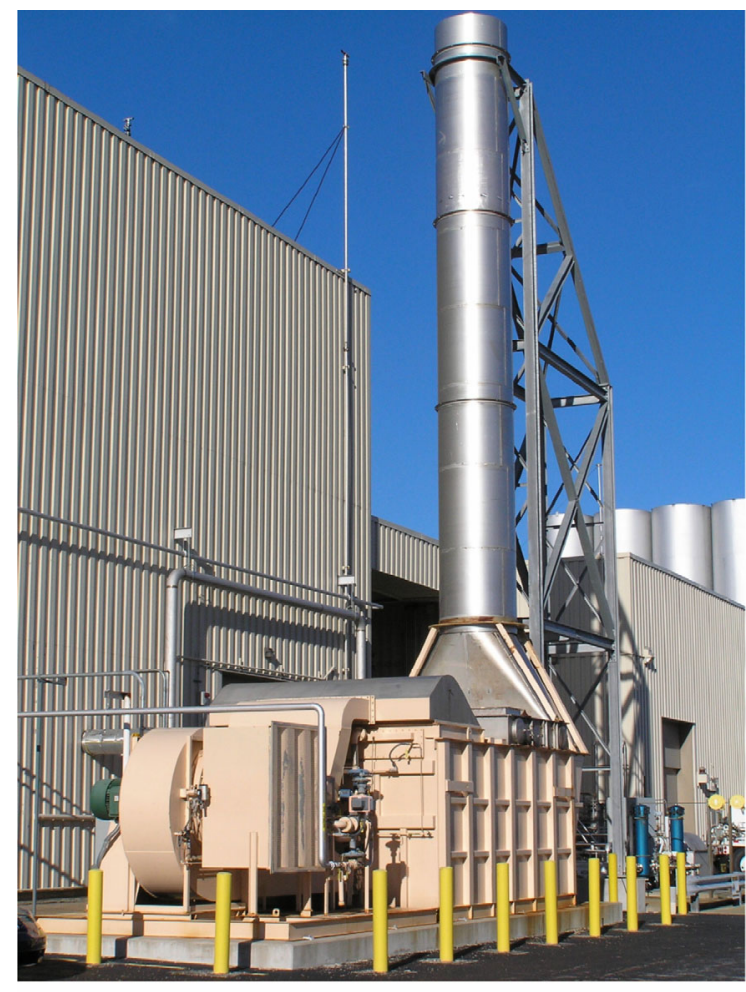

Figure 8.-Nonvitiated 465-psia air heater.

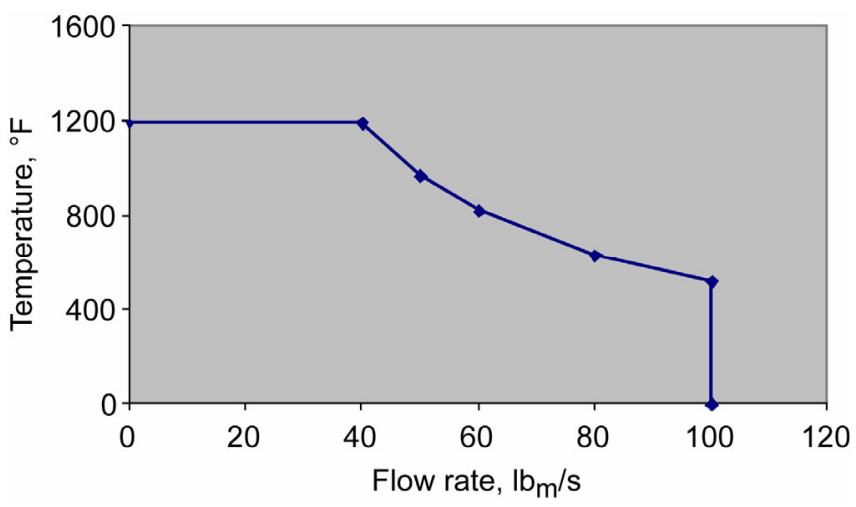

Figure 9.-Capability of the 465-psia air heater.

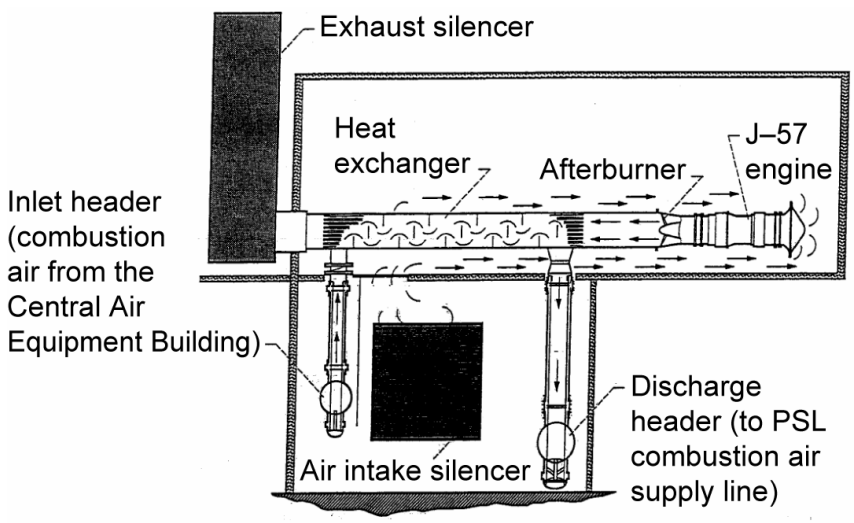

Figure 10.—Combustion air heater. 
planned. Recently, a mixer was added to the natural-gas distribution line to improve the fuel distribution of the natural gas to the afterburner. These modifications have increased the heat exchanger outlet temperatures to over $900{ }^{\circ} \mathrm{F}\left(482^{\circ} \mathrm{C}\right)$. Additional modifications, which are in the design phase, are planned for 2006. The goal is to attain the full $1200{ }^{\circ} \mathrm{F}\left(649{ }^{\circ} \mathrm{C}\right)$ exchanger outlet temperatures and meet the advertised conditions of the original design.

\section{Flight Safety Testing Capability Improvements}

Icing can occur on aircraft turbine engines as they fly through clouds or as they sit idling on the ground during cold, foggy conditions. The water droplets from the clouds can freeze and build up on the engine inlet components. This buildup can reduce engine performance if the ice impacts the airflow into the engine. The ice can also cause physical damage to the engine if it sheds and strikes engine hardware. In the United States, the Federal Aviation Administration, and in Europe, the European Aviation Safety Agency require aircraft turbine engine manufacturers to certify that their engines can operate in these icing conditions without serious loss of power or thrust and without damage to the engine hardware as a result of ice shedding.

Flight tests in actual conditions or ground testing in simulated conditions can be used to investigate the engine icing conditions. Cloud and flight conditions can be accurately and safely investigated and repeatedly simulated in an altitude test facility at any time of the year. The PSL's ability to simulate cold inlet conditions through a wide range of altitudes makes the PSL an ideal facility to support engine icing research and certification.

Conceptual design efforts are underway to define a system that can deliver both supercooled water droplets and ice particles to engines mounted in the facility. The range of the system parameters is shown in table II.

\section{Facility Operator Training Improvements}

The PSL facility is staffed with a team of engineering and technical personnel with unique expertise and many years of experience in all aspects of altitude engine testing and research. The challenge in any organization is to develop and maintain these skills and corporate knowledge. Recent trends with an aging workforce and an emphasis on operating the facilities with fewer personnel has made this challenge more difficult. In this climate, the need to more quickly and efficiently train qualified facility operators has arisen. Operating a major research facility like the PSL requires a substantial cost in the form of manpower and utilities. As a result, an alternative to operating the full facility for training purposes was developed.
TABLE II.-CONCEPTUAL PSL ICING SYSTEM PARAMETERS

\begin{tabular}{|c|c|c|}
\hline Parameter & $\begin{array}{l}\text { Minimum } \\
\text { required }\end{array}$ & $\begin{array}{c}\text { Maximum } \\
\text { desired }\end{array}$ \\
\hline Altitude, $\mathrm{ft}(\mathrm{km})$ & $\begin{array}{r}5000 \text { to } 25000 \\
(1.5 \text { to } 7.6)\end{array}$ & $\begin{array}{r}0 \text { to } 40000 \\
(0 \text { to } 12.2)\end{array}$ \\
\hline Total inlet air temperature, ${ }^{\circ} \mathrm{F}\left({ }^{\circ} \mathrm{C}\right)$ & $\begin{array}{r}-22 \text { to } 30 \\
(-30 \text { to }-1)\end{array}$ & $\begin{array}{l}-40 \text { to } 32 \\
(-40 \text { to } 0)\end{array}$ \\
\hline Mach number & 0.15 to 0.60 & ----------- \\
\hline Inlet airflow rate, $\mathrm{lb}_{\mathrm{m}} / \mathrm{s}(\mathrm{kg} / \mathrm{s})$ & $\begin{array}{r}10 \text { to } 330 \\
(4.5 \text { to } 149.7)\end{array}$ & ---------- \\
\hline $\begin{array}{l}\text { Liquid water content, } \\
\qquad \mathrm{lb}_{\mathrm{m}} / \mathrm{ft}^{3} \times 10^{-5}\left(\mathrm{~g} / \mathrm{m}^{3}\right)\end{array}$ & $\begin{array}{l}1.25 \text { to } 13.7 \\
(0.2 \text { to } 2.2)\end{array}$ & $\begin{array}{l}0.94 \text { to } 17.5 \\
(0.15 \text { to } 2.8)\end{array}$ \\
\hline Mean effective droplet diameter, $\mu \mathrm{m}$ & 15 to 25 & 15 to 50 \\
\hline $\begin{array}{l}\text { Ice water content, } \\
\qquad \mathrm{lb}_{\mathrm{m}} / \mathrm{ft}^{3} \times 10^{-5}\left(\mathrm{~g} / \mathrm{m}^{3}\right)\end{array}$ & $\begin{array}{l}3.1 \text { to } 43.7 \\
(0.5 \text { to } 7.0)\end{array}$ & ----------- \\
\hline Mean ice particle diameter, $\mu \mathrm{m}$ & 100 & 1000 \\
\hline Horizontal extent, mi (km) & $\begin{array}{l}3.1 \text { to } 311 \\
\text { ( } 5 \text { to } 500 \text { ) }\end{array}$ & ----------- \\
\hline Run time per test condition, min & 10 & 45 \\
\hline
\end{tabular}

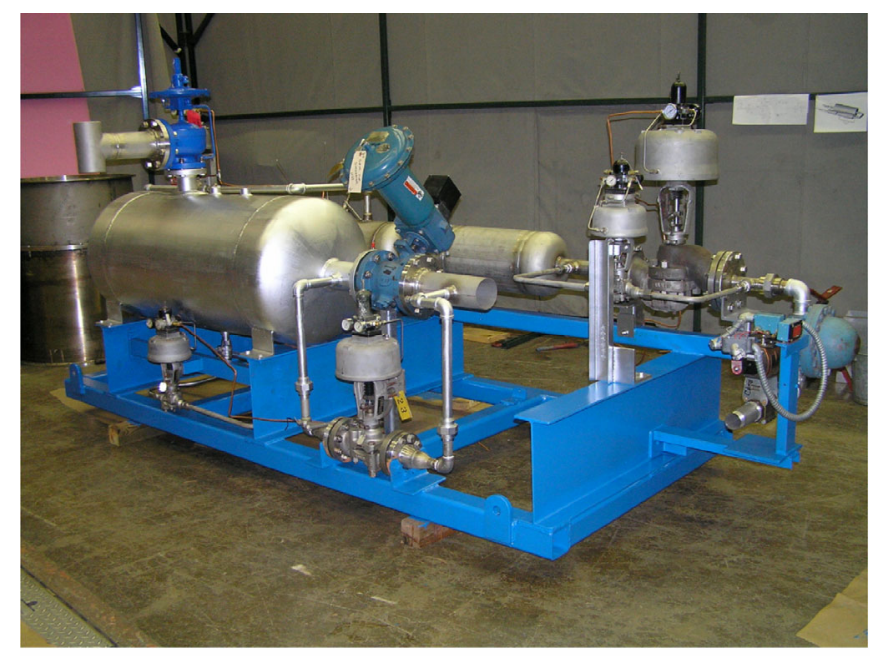

Figure 11.-PSL-5 facility simulator in fabrication.

PSL-5 is a scaled-down version of the PSL facility designed specifically for training operators on how to run the actual altitude test cells, PSL-3 and PSL-4 (fig. 11). Service air will be used to run the PSL -5 facility simulator and to provide the simulated airflow to create the same pressure drops seen by valves during actual facility operation. This simulation will give operators-in-training an opportunity to practice facility control procedures during normal test conditions. It will also enable operators to practice emergency shutdown procedures, which are extremely important and cannot be practiced while an actual test engine is being run. 
To make the simulation as accurate as possible, PSL-5 will be wired directly to the actual PSL facility control system, and thereby, all controls for the simulator will look and act exactly like the actual facility controls. Another advantage is that operators-in-training can run the simulator at any time and for as long as needed during and between ongoing test programs. Use of this simulator will preclude the need to spend the cost and time to set up and run the full facility for training purposes.

\section{Observations and Conclusions}

Over the years, Glenn's PSL has supported a large variety of national program requirements from within NASA, military, and commercial organizations. The services provided to customers have established the PSL as one of the premier national facilities for altitude engine testing.

Factors that contribute to the success of Glenn's PSL include

- The expertise and efficiency of Glenn personnel in conducting propulsion system research

- The high inlet temperature and pressure capabilities of the PSL

- Flexible policies that enable Glenn to adapt to changing test schedules (Glenn has a history of providing test cell availability when required and adjusting timetables to meet the needs of advanced engine testing.)

- Investments in new data system technology in the PSL that provides its customers with the flexibility and accuracy they require
Direct feedback from customers has confirmed that the PSL is a good value for altitude engine testing.

Glenn's PSL has been designated as a facility critical to the needs of future NASA and other Agency programs. As a result, the facility was included in the new Aeronautics Test Program established by NASA Headquarters to ensure its continued availability and to invest in new capabilities.

Glenn's PSL has made and will continue to make the improvements necessary to increase productivity, improve data accuracy, and expand facility test capabilities to meet the changing needs of aerospace propulsion testing.

The Glenn point of contact for all questions regarding the PSL, its capabilities, and use is

\author{
Propulsion Systems Laboratory (PSL) Manager \\ NASA Glenn Research Center \\ 21000 Brookpark Road \\ Cleveland, Ohio 44135 \\ Phone: 216-433-4000
}

\section{References}

1. Soeder, Ronald H., 1994, "NASA Lewis Propulsion Systems Laboratory Customer Guide Manual," NASA TM106569.

2. Panek, Joseph W., 2001, "Verifying Data Integrity of Electronically Scanned Pressure Systems at the NASA Glenn Research Center,"NASA/TM-2001-211155. http://gltrs.grc.nasa.gov/cgi-bin/GLTRS/browse.pl?2001/ TM-2001-211155.html. 


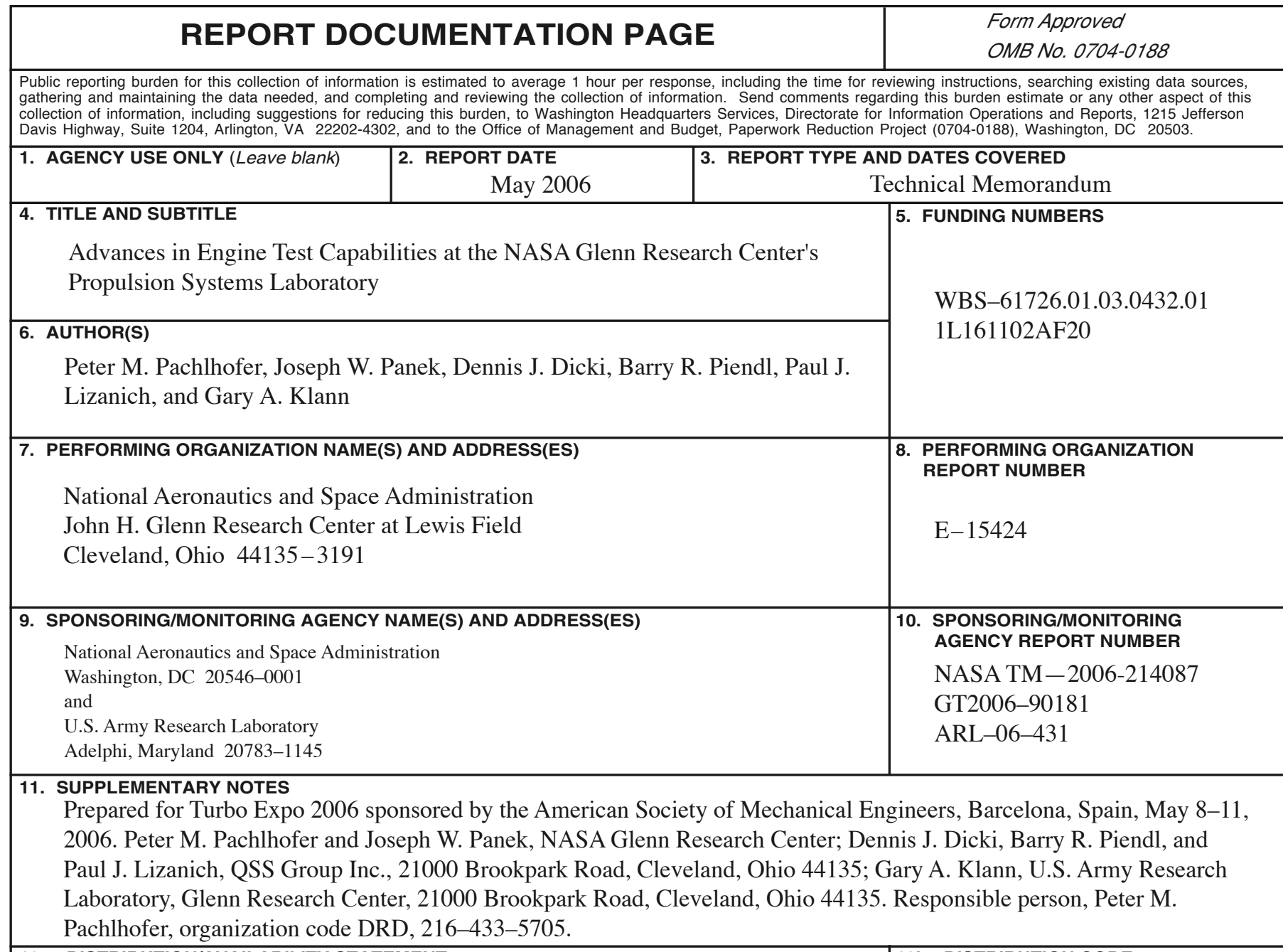

\begin{tabular}{|l|l|l|l|}
\hline 12a. DISTRIBUTION/AVAILABILITY STATEMENT & 12b. DISTRIBUTION CODE
\end{tabular}

Unclassified - Unlimited

Subject Categories: 07 and 09

Available electronically at http://gltrs.grc.nasa.gov

This publication is available from the NASA Center for AeroSpace Information, 301-621-0390.

13. ABSTRACT (Maximum 200 words)

The Propulsion Systems Laboratory at the National Aeronautics and Space Administration (NASA) Glenn Research Center is one of the premier U.S. facilities for research on advanced aeropropulsion systems. The facility can simulate a wide range of altitude and Mach number conditions while supplying the aeropropulsion system with all the support services necessary to operate at those conditions. Test data are recorded on a combination of steady-state and highspeed data-acquisition systems. Recently a number of upgrades were made to the facility to meet demanding new requirements for the latest aeropropulsion concepts and to improve operational efficiency. Improvements were made to data-acquisition systems, facility and engine-control systems, test-condition simulation systems, video capture and display capabilities, and personnel training procedures. This paper discusses the facility's capabilities, recent upgrades, and planned future improvements.

\section{SUBJECT TERMS}

Turbine engines; Test equipment; Test facilities; High altitude tests

\begin{tabular}{|c|c|c|}
\hline $\begin{array}{c}\text { 17. SECURITY CLASSIFICATION } \\
\text { OF REPORT } \\
\text { Unclassified }\end{array}$ & $\begin{array}{c}\text { 18. SECURITY CLASSIFICATION } \\
\text { OF THIS PAGE } \\
\text { Unclassified }\end{array}$ & $\begin{array}{c}\text { 19. SECURITY CLASSIFICATION } \\
\text { OF ABSTRACT } \\
\text { Unclassified }\end{array}$ \\
\hline
\end{tabular}



